\title{
2 Vulnerabilities of rural women to climate extremes
}

\section{A case of semi-arid districts in Pakistan}

\author{
Ayesha Qaisrani and Samavia Batool
}

\section{Introduction}

Gender is often discussed in the discourse on climate change, yet rarely forms a core element of research and policy perspectives. Recent literature recognizes that climate change impacts are not gender neutral but affect women disproportionately (Babugura 2010; MacGregor 2010; Rao et al. 2017). Vulnerabilities associated with climate change are accentuated because of women's pre-existing marginalization and may lead to 'inequity traps'. Conversely, climate adaptation options are also gendered and may not always result in equal increased resilience for women, girls, men and boys (UNDP 2013; Angula and Menjono 2014). Such growing recognition of disparate climate change impacts calls for more gender-just development and climate policies so that women's adaptive capacities can be enhanced, irrespective of their varying socio-economic status (Tiani et al. 2016).

Given the current focus in the literature on differential climate impacts (UNDP 2013; Rao et al. 2017; Petesch et al. 2018), it is pertinent to consider the geographical aspects that may exacerbate existing climate change threats for both men and women. Accordingly, this chapter focuses on semi-arid locales and assesses how men and women are affected by climate change in a water-scarce geographical setting.

This chapter does not homogenize the experiences of rural women in the context of climate change, rather it illustrates the various pathways through which women's interaction with the environment and natural resources shapes their vulnerability. Following Hahn et al.'s (2009) and Panthi et al.'s (2016) conceptualizations of vulnerability, women's vulnerability is analyzed in terms of their exposure, sensitivity and adaptive capacity to climate change impacts. It is recognized that women's vulnerability to climate change not only depends on their gender; rather, other factors such as their age, geographic location, socio-economic background, household structure and position in the household and community play a role in defining their exposure, sensitivity and adaptive capacity to climate change. In that sense, the chapter brings into play discussions on intersectionality, with contextspecific examples taken from the fieldwork that help explain women's vulnerability in different situations (Nizami and Ali 2017). Furthermore, we briefly touch upon the climate change policy framework of Pakistan 
and provide a policy-oriented way forward for enhancing the resilience of vulnerable women in rural semi-arid regions.

The insights emerge from two PRISE projects in Pakistan focusing on migration and cotton value chains in the semi-arid regions of Dera Ghazi Khan, Faisalabad and Mardan districts., ${ }^{2,3}$ For this study, we focus on rural areas in Dera Ghazi Khan and Faisalabad districts, ${ }^{4}$ Punjab province. Based on mixed-methods data collected between December 2016 and January 2017 , this chapter draws on household surveys $(\mathrm{n}=200$ per district) and gender-segregated focus group discussions $(\mathrm{n}=8$ per district, 4 each with men and women). Two union councils (UCs) were targeted in each district, and one village was selected from each union council. UC Sokar (village: Mor Jhangi) and UC Kala (village: Basti Raman) were selected in Dera Ghazi Khan and UC 116 (village: Bhainian) and UC 39 (village: Gangapur) were selected in Faisalabad. The household survey was targeted at mainly farming households, most of whom were cotton farmers. Table 2.1 summarizes the sample selection from each district with respect to landholding.

In addition, we carried out focus group discussions with between eight and twelve women and men of different economic backgrounds in the age group 18-65 years. The participants were randomly selected from the stratified sample list of the households surveyed. The discussions in the focus groups were targeted at gathering information about the gendered impacts of climate change, gender roles and responsibilities in post-disaster scenarios, and perceptions about gender differences in climate vulnerability. All the focus group participants were either full- or part-time workers in cotton fields. Women were mostly involved in cotton picking, whereas men were responsible for cultivation and crop management.

This chapter is organized as follows. We begin by introducing the contextual background of the study areas, then present the field evidence, and finally summarize our findings and offer some conclusions.

\section{Contextual background}

Pakistan, a country of over 208 million people as of 2017 (Population Census 2017), has a varied geographical terrain ranging from the coastal areas in the south to the mountainous ranges of Hindu Kush, Karakoram and the Himalayas in the north. The country lies in the arid-humid ecological range, with 88 per cent of its area characterized as arid to semi-arid (Farooq et al. 2009). According to the Pakistan Meteorological Department (PMD) maps, about 25-30 per cent of Pakistan's total area receives rainfall of 250-500mm annually and is classified as semi-arid (Rasul et al. 2012). These semi-arid regions contain some of the country's most fertile land and serve as the breadbasket for the growing population (Saeed et al. 2016). These areas are densely populated and natural resource-based livelihoods are the mainstay of the rural people. For instance, Dera Ghazi Khan has a population density of $245.7 / \mathrm{km}^{2}$ and Faisalabad has a population density of 1321/km² (Population Census 2017). 
Table 2.1 Sample selection by district

\begin{tabular}{|c|c|c|c|c|c|c|c|}
\hline District & $\begin{array}{l}\text { Union } \\
\text { Council }\end{array}$ & Village & $\begin{array}{l}\text { No. of landless } \\
\text { agrarian } \\
\text { workers }\end{array}$ & $\begin{array}{l}\text { No. of small } \\
\text { landholders (owning } \\
\text { less than } 12.5 \\
\text { acres of land) }\end{array}$ & $\begin{array}{l}\text { No. of large } \\
\text { landholders (owning } \\
\text { land greater than } \\
12.5 \text { acres) }\end{array}$ & $\begin{array}{l}\text { No. of } \\
\text { non-farm } \\
\text { bouseholds } \\
\text { (non-agrarian) }\end{array}$ & Total \\
\hline \multirow[t]{2}{*}{ Dera Ghazi Khan } & Kala & Basti Raman & 25 & 25 & 25 & 25 & 100 \\
\hline & Sokar & MorJhangi & 25 & 25 & 25 & 25 & 100 \\
\hline Faisalabad & $\begin{array}{l}\text { UC } 116 \\
\text { UC } 39\end{array}$ & $\begin{array}{l}\text { Bhainian } \\
\text { Gangapur }\end{array}$ & $\begin{array}{l}25 \\
25\end{array}$ & $\begin{array}{l}25 \\
25\end{array}$ & $\begin{array}{l}25 \\
25\end{array}$ & $\begin{array}{l}25 \\
25\end{array}$ & $\begin{array}{l}100 \\
100\end{array}$ \\
\hline
\end{tabular}

Source: Qaisrani et al. (2018). 
In terms of future climate risks for Pakistan, the Intergovernmental Panel on Climate Change (IPCC) Fifth Assessment Report (AR5) finds a higher likelihood of increase in warming, glacial melting rate and precipitation rate (CDKN 2014). The annual mean temperature alone has increased by $0.57^{\circ} \mathrm{C}$ over the last century. Not only this, heatwave days increased by 31 from 1981 to 2007 (ADB 2017). Similarly, high variations are found in the precipitation pattern. An increase in average monsoon precipitation, for example, was observed in Punjab region during 2009-2015, which triggered heavy flooding in 2010, 2011 and 2012 in different parts of Punjab (ibid). These conditions are impacting soil quality and water availability (IPCC 2013). As a result, increased desertification and land degradation are shrinking arable lands, leading to declining agricultural production, complete crop failures through floods or pest attacks, lower incomes, health issues for livestock and humans through the spread of water- and heatborne disease, and adverse impacts on lives and property during extreme events (Hussain 2010). Unreliable rains expose the agriculture sector to serious jeopardy - too much rain, especially in the northern regions, lead to floods downstream, washing away standing crops, while a lack of rain creates a drought-like situation in the semi-arid plains, hampering agricultural production (Zaman et al. 2009; Hasson et al. 2017). Unsustainable crop production threatens to further worsen the food insecurity situation in Pakistan, as declining natural resources have to feed a rapidly growing population (Rasul et al. 2012; Nizami and Ali 2017).

Limited availability of water particularly in semi-arid lands makes these regions highly vulnerable to the changing climate. Future projections of water availability for semi-arid regions show a downward trend towards the end of this century (Bates et al. 2008). It means that semi-arid regions are on the verge of convergence with arid and hyper-arid lands (ibid.). In addition, demand for water for agricultural purposes in arid and semi-arid regions of Asia is also projected to rise by 10 per cent in the case of a $1{ }^{\circ} \mathrm{C}$ temperature increase (Fischer et al. 2002; Liu 2002).

Both Dera Ghazi Khan and Faisalabad are in the wheat- and cottonproducing belt of semi-arid Punjab (Batool and Saeed 2017). About 80 per cent of the population of Dera Ghazi Khan is rural (Pakistan Bureau of Statistics 2017), largely agriculturists growing wheat, cotton, sugar cane and rice. The Dera Ghazi Khan district contains the Koh-e-Suleiman mountains on the eastern border, while its western side is marked by sandy plains and the Indus River (Malana and Khosa 2011). Some of the villages near the plains are irrigated by extensive canal systems; however, many located closer to the mountain ranges are irrigated by unreliable mountain streams (ibid.) which often flood the farms during monsoon rains, causing havoc for the poor farmers (Salik et al. 2017). Saeed et al. (2014) report that over the five years between 2009 and 2014, the frequency of rainfall decreased in South Punjab, where Dera Ghazi Khan is situated; however, the intensity of the monsoon rains increased. For the rest of the year, the climate is dry, the rainfall is scanty and the district suffers from water shortage, especially in areas 
not irrigated by the canal system (Malana and Khosa 2011). The district historically struggles with waterlogging and salinity issues due to seepage from canals built during the colonial period (LEAD Pakistan 2015). This makes the groundwater bitter and unfit for drinking. Many villages depend on the government to supply drinking water, which is provided through pipes at certain filter points (Qaisrani et al. 2018). Table 2.2 shows access to safe drinking water and sanitation facilities in the study districts.

As noted above, even though average annual rainfall levels have not changed much, the timings and patterns of rainfall have changed, with consequences for natural resource-based livelihoods (WFP 2018). In particular, the late arrival of monsoon rains disrupts the crop growing season, adversely affecting farmers' yields (ibid.). In addition, the frequency of excessive rains has increased over time, causing flooding in the area (Salik et al. 2017; WFP 2018). These factors, along with low levels of socio-economic

Table 2.2 Socio-economic indicators by district

\begin{tabular}{|c|c|c|c|c|}
\hline S. no & Indicator & $\begin{array}{l}\text { Dera Ghazi } \\
\text { Khan }\end{array}$ & Faisalabad & Year and Source \\
\hline 1. & Population & $2,872,201$ & $7,873,910$ & $\begin{array}{l}2017 \text { (Population } \\
\text { Census Summary) }\end{array}$ \\
\hline 2. & $\begin{array}{l}\text { Percentage of rural } \\
\text { population }\end{array}$ & $80 \%$ & $52 \%$ & $\begin{array}{l}2017 \text { (Population } \\
\text { Census Summary) }\end{array}$ \\
\hline 3. & $\begin{array}{l}\text { Net primary enrolment } \\
\text { rate for women } \\
\text { (rural) }\end{array}$ & $51 \%$ & $72 \%$ & 2014-15 PSLM \\
\hline 4. & $\begin{array}{l}\text { Net primary enrolment } \\
\text { rate for men (rural) }\end{array}$ & $71 \%$ & $72 \%$ & 2014-15, PSLM \\
\hline 5. & $\begin{array}{l}\text { Women's literacy }(15 \\
\text { years and older) } \\
\text { (rural) }\end{array}$ & $16 \%$ & $48 \%$ & 2014-15, PSLM \\
\hline 6. & $\begin{array}{l}\text { Men's literacy (15 years } \\
\text { and older) (rural) }\end{array}$ & $47 \%$ & $66 \%$ & 2014-15, PSLM \\
\hline 7. & $\begin{array}{l}\text { Improved drinking } \\
\text { water facility (tap } \\
\text { water and motor } \\
\text { pump) (rural) }\end{array}$ & $37 \%$ & $70 \%$ & 2014-15, PSLM \\
\hline 8. & $\begin{array}{l}\text { Improved sanitation } \\
\text { facility (rural) }\end{array}$ & $45 \%$ & $86 \%$ & 2014-15, PSLM \\
\hline 9. & $\begin{array}{l}\text { Multidimensional } \\
\text { poverty rate (district } \\
\text { level) }\end{array}$ & $63.7 \%$ & $19.4 \%$ & GoP, 2016 \\
\hline 10. & $\begin{array}{l}\text { Male to female sex ratio } \\
\text { (district level) }\end{array}$ & 108.2 & 108.6 & $\begin{array}{l}\text { Population Census, } \\
2017\end{array}$ \\
\hline
\end{tabular}

Source: Multiple sources. 


\section{Ayesha Qaisrani and Samavia Batool}

development, have gendered implications. Men are deemed responsible for crop production, crop protection, sale of output and water management. Women contribute at various stages of crop production; however, their farm work largely goes unrecognized (Samee et al. 2015). They are also actively involved in livestock management. Dera Ghazi Khan has one of the highest multidimensional poverty rates in Pakistan, with 63.7 per cent of its population living in poverty (GoP 2016). Such wide-ranging poverty and inequality in access to services and opportunities results in a lower socio-economic status for many women in the district.

On the other hand, while the land in the rural areas of Faisalabad is very fertile, it is also the largest industrial district of Pakistan. The urban-rural ratio is fairly even in the district with about 52 per cent of its population being rural (Pakistan Bureau of Statistics 2017). The rural areas are irrigated through the extensive canal system. Maintenance problems, however, cause waterlogging and salinity. Groundwater is brackish and unsuitable for human consumption or even agricultural or livestock usage due additionally to industrial waste polluting the water quality (D'Souza 2006; Salik et al. 2017).

The maximum summer temperature in Faisalabad can go up to $50^{\circ} \mathrm{C}$, while the winter lows can drop down to $-2^{\circ}$ (Abbas 2013). The average temperature of the district is increasing, especially in the winter months (Cheema et al. 2006). Cheema et al. (2006) report an increase of $0.22^{\circ} \mathrm{C}$ in Faisalabad between 1945 and 2004. Erratic rainfall and a rise in the frequency and intensity of heat waves are increasingly affecting crop production in the area (IPCC 2013; Saeed et al. 2016). Mueller et al. (2014) report that heat waves in winter in Faisalabad adversely affect wheat yields. Average temperature projections from KNMI Climate Explorer (2017) show increasing temperature trends for both Faisalabad and Dera Ghazi Khan (Figures 2.1 and 2.2).
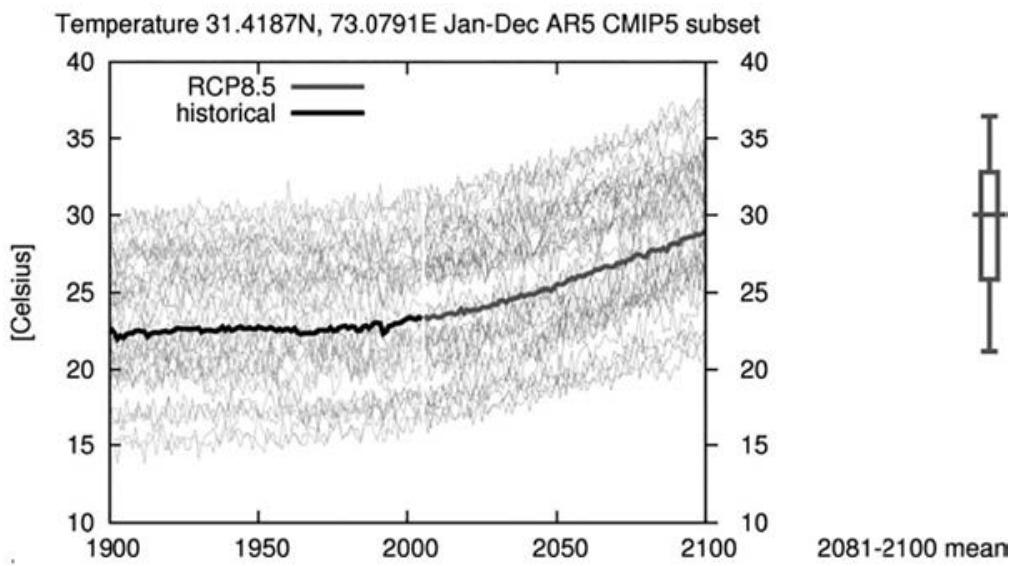

Figure 2.1 Temperature trend for Faisalabad.

Source: KNMI Climate Explorer with RCP 8.5 (2017). 
Temperature change $30.0325 \mathrm{~N}, 70.6402 \mathrm{E}$ Jan-Dec wrt 1986-2005 AR5 CMIP5 subset

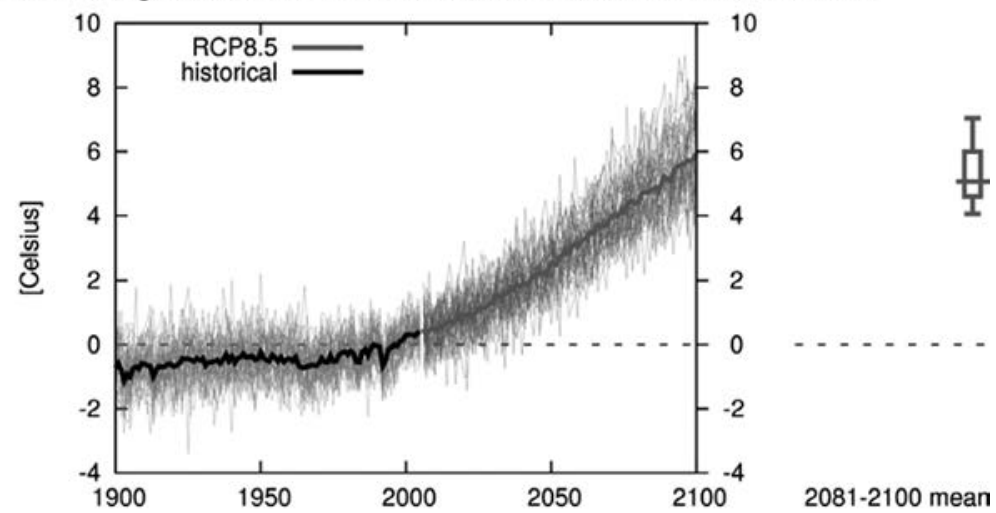

Figure 2.2 Temperature trend for Dera Ghazi Khan.

Source: KNMI Climate Explorer with RCP 8.5 (2017).

Due to a thriving industrial sector, the socio-economic status of Faisalabad is better than that of Dera Ghazi Khan. The multidimensional poverty rate of Faisalabad is 19.4 per cent, significantly lower than in Dera Ghazi Khan (GoP and UNDP 2016). Net primary enrolment rates for both men and women are the same at 72 per cent, however, adult female literacy is much lower (48 per cent) than adult male literacy (66 per cent) (Pakistan Bureau of Statistics 2015a, b) (Table 2.2). The labour force participation rate for women (27.3 per cent) is higher than the national average (23.7 per cent); however, female participation is about three times lower than male labour force participation (Khan et al. 2014; World Bank 2018). In the absence of recent data, 2008 estimates show that 60.5 per cent of the female labour force was employed in agriculture, 21.4 per cent in industry and 18.1 per cent in services in Faisalabad (Khan et al. 2014).

While socio-economic indicators reflect better conditions for gender equality in Faisalabad (cf. Table 2.2), traditional gender roles and patriarchal structures reflect similar trends to those observed for Dera Ghazi Khan (Khan et al. 2013; Akhtar et al. 2018). A report by the Pakistan Commission for the Status of Women (PCSW 2018) shows that in rural Punjab, married women in the age group 15-64 spend an average of 29 hours a week on unpaid domestic work. Rural women from poorer economic backgrounds in both Dera Ghazi Khan and Faisalabad are often involved in selling milk, eggs and meat, which allows them to earn a meagre income. Despite their active involvement in farming, most women are scarcely involved in decision making regarding land use, livestock sale and purchase, and crop choices (Ishaq and Memon 2016; PCSW 2018).

Against this background, this study attempts to assess how climate change may influence gender relations in Dera Ghazi Khan and Faisalabad. In particular, it explores the different ways in which climate change is 
perceived, experienced and responded to by different individuals based on their social, cultural, economic and demographic backgrounds (MacGregor 2010; UNDP 2013; UN Women 2018; Petesch et al. 2018).

\section{Evidence from the field: climate change and vulnerabilities for women}

A contextual understanding of how climate change may impact the lives of women in agricultural households is important for the analysis of how socio-economic class, age and generation interact with each other to increase or decrease women's vulnerabilities and adaptative capacities. There are differences and similarities not only between the two districts of Dera Ghazi Khan and Faisalabad, but also within communities and households, depending on their roles and responsibilities and the nature of their work.

\section{Class matters}

Women of diverse socio-economic classes experience climate change differently. In both Dera Ghazi Khan and Faisalabad, women's experience of climate extremes is quite different between those belonging to landless or small-farm households and those belonging to better-off households with large landholdings. About 63 per cent of private farms in Punjab are 5 acres or smaller, and cover only 22 per cent of total land in Punjab, revealing that a majority of the rural population are smallholders (Agricultural Census 2010). Poorer women from households with no land or from smallholdings are more involved in agricultural activities than women from large landholder households and better socio-economic backgrounds (UN Women 2018). They are usually involved in sowing, weeding, crop picking and harvesting, while men are largely responsible for land preparation, irrigation and harvesting (Samee et al. 2015). As well as working on their own farms, women from poorer households are hired as daily wage labourers for cotton picking during the harvest season, especially in Dera Ghazi Khan (Batool and Saeed 2018). Their direct involvement in and dependence on agriculture makes their livelihoods more at risk, subjecting them to income shocks if agricultural productivity is affected by climate extremes. As rural areas are transforming at different rates, unlike Dera Ghazi Khan, where poorer women are still largely engaged in agricultural activities, in Faisalabad, they are more likely to engage with non-farm activities such as paid domestic work (Salik et al. 2017; Qaisrani et al. 2018). Such non-agricultural jobs safeguard women from experiencing the direct impacts of climate change and hence lessen their vulnerability.

In an earlier paper (Qaisrani et al. 2018), we showed that Faisalabad in general had lower scores on livelihood vulnerability, owing to higher adaptive capacity than Dera Ghazi Khan and lesser exposure to climate change impacts. Dera Ghazi Khan appears to be experiencing the double jeopardy of higher exposure to climate change in terms of frequent floods 
plus dry spells and rising temperatures, contributing to a higher incidence of complete crop failure. With high levels of multidimensional poverty, a high dependency ratio and lower access to climate information, the population has lower adaptive capacities to respond to these impacts (ibid.). Poorer women told us how difficult it was to work in the fields, especially in the summer, when temperatures rise as high as $49^{\circ} \mathrm{C}$ (PMD 2018). They reported that they usually get sunburnt and often experience heatstroke. This risk pattern is particularly visible in young girls and elderly women. Sajida, 18, from a landless agrarian household in village MorJhangi in Dera Ghazi Khan, said: "It is getting difficult for us to pick cotton due to extreme heat in the field these days. My grandmother got ill the other day due to heat and she had to rest for a week."

Unreliable rains and frequent floods in Dera Ghazi Khan adversely impact women's work patterns (Zaman et al. 2009; Hasson et al. 2017). They often have to spend more time and energy on crop maintenance and livestock management, leaving them with little time to spare for domestic responsibilities. According to secondary district-level data, only 37 per cent of households in rural Dera Ghazi Khan have access to improved drinking water facilities and a mere 45 per cent have improved sanitation facilities (MICS 2018) (Table 2.2). Women from about 26 per cent of households have to walk more than 30 minutes to access drinking water (MICS 2018). With more time spent on fetching water, the time for vital household activities like cooking and child care is reduced.

Whether they are working in their own fields or working as day-wage labourers, women's efforts, although crucial, are valued less in monetary terms. Many women farmers work for minimal remuneration (much lower than men's) in other farmers' fields. Their work on the family farm goes unrecognized socially as they are considered 'helpers' of their male counterparts (cf. Rao et al. 2019). For waged workers, the low remuneration is further adversely affected during shocks like floods. Women's incomes decline further and some even lose their jobs when crops fail. Salma, 37, a cotton picker on a large landholder's farm in village MorJhangi, Dera Ghazi Khan said: "Men can easily migrate for work whereas we have to stay here (at home) to take care of the family. After the floods (of 2010), my daily wage was decreased from Rs. 200 (\$1.62) per bale of cotton (1 bale = $177.8 \mathrm{~kg}$ ) to Rs. 75 (\$0.61). Even before the floods, my husband earned more than me (Rs. 350 per bale $=\$ 3.2)$."

This quote reveals how men and women experience vulnerability differently in case of climate-related events. It not only reflects the gendered wage disparities between men and women but also highlights the differences in opportunities available to them. While the livelihoods of both men and women are affected by floods, men are more likely to find other opportunities by migrating. Women are less likely to do so owing to both mobility restrictions and their domestic responsibilities. This sentiment was also observed in Faisalabad, where cotton picking is one of the main livelihood activities for poorer women. 
In both districts, men are regarded as the primary breadwinners and women as 'helpers' and minor contributors to the household income. In village Gangapur in Faisalabad, 35-year-old Asma Bibi, who belongs to a small-landholder household, said: "Men are usually over-burdened as they have to work hard and earn for all of us (household members). They have to go out of town to find work whereas we (women) just have to stay at home or we just go to the fields nearby to pick cotton, which is not a difficult task."

While such sentiments show that women undermine their own contribution to agricultural work, they also reflect the neglect that women in agriculture have historically experienced in these areas (Samee et al. 2015). In addition, working in the fields was considered necessary for women to make ends meet in the lower-income households, and not a sign of empowerment. As 29-year-old Naveeda, belonging to a landless household in Basti Raman in Dera Ghazi Khan remarked: "I work on their (large landowner's) field to earn some extra money during harvest season, but women's place is at home to take care of their family".

In Dera Ghazi Khan and Faisalabad, women are rarely seen as the principal farmers. Discussions in both districts showed that women are often deemed 'secondary farmers' due to their 'seasonal' or 'need-based' involvement in particular stages of agricultural production. In cotton production, their involvement is particularly important at the time of picking. They are contracted by large farm-holders at lower wages than men. However, their income from this activity is often the only remuneration they receive in the year for their own work. In wheat production as well, in both the districts, lower-income women were involved in wheat harvesting but were largely paid in kind rather than in cash. The women do not consider cotton picking too draining physically but harvesting wheat is perceived to be a difficult task and often the entire family, including young girls, participate in the process. In Faisalabad, it was reported that scores of young girls take extended breaks from school to help their families pick cotton. Humeira Khalid, 36, a school teacher in village Bhainian in Faisalabad said: "One of the best students of my class has left school and is not appearing in exams because it's the harvest season. She is working on the farm."

Such physically exhausting work takes its toll on the health of the women working in the fields. Rising temperatures and lack of rains increase the risk of pest attacks on crops (Memon 2011). As a result, farmers increase the use of pesticides, which can be injurious to health due to lack of proper safety measures for cotton picking. In both Dera Ghazi Khan and Faisalabad, cotton pickers, mostly women and young girls, risk developing skin allergies from pesticide residues on the cotton bolls. These risks are particularly high for pregnant cotton pickers (Batool and Saeed 2017).

Women who are not directly involved in farm activities are also vulnerable to secondary impacts of climate events. The secondary impacts often manifest themselves in reduced household income, which has significant implications for food security and spending on health and education. Not 
only this, women are now also pursuing more off-farm employment to supplement household income while still maintaining existing household responsibilities. In Dera Ghazi Khan, for instance, many women from lowerand middle-income backgrounds who stay at home contribute to the household income by embroidering scarves and shawls for private contractors. However, the remuneration is nominal and the task quite time-consuming, as noted also in other studies of women's home-based work such as the lace makers of Narsapur (Mies 1982). Tehmina, 27, from Dera Ghazi Khan said: "One dupatta (shawl) takes around two weeks to complete. We have to look after the household too, and this is slow work. At the end of the month, we only get PKR 100-150 (\$1.25) for a dupatta that the contractors sell for thousands in the market. They earn profits on our hard work."

Women from lower-income households are generally more mobile within the vicinity of the village. They are often also involved in water collection and doing domestic chores for other households. In Faisalabad, women's mobility appeared to be more relaxed than in Dera Ghazi Khan across income groups. Most women from lower-income households in Faisalabad reported that they are free to move within the village to collect water or to do paid domestic work. Women from both lower- and middle-income groups said they had the freedom to visit relatives and friends. Women here were more visible in public spaces such as markets and streets, walking around without being accompanied more often than in Dera Ghazi Khan. This difference between the two districts is also captured by the Women's Economic and Social Empowerment (WESE) Index of 2018, according to which the score for women in rural Faisalabad is 54 (medium category) compared to Dera Ghazi Khan, where the score is 34 (low category) (UN Women 2018).

Among the wealthier households or the more politically powerful families in the villages, women's mobility is restricted due to notions of the families' 'honour' and 'prestige'. In gender-segregated focus group discussions in Dera Ghazi Khan, many respondents, both women and men, felt that 'noble' women are expected to stay at home, while the men are responsible for earning. Religious interpretations and social norms structure gender roles in society, where women's responsibility is to look after the private realm, while the men's duty is to earn and provide for the household. Seema, a 22-year-old woman in Basti Raman in Dera Ghazi Khan, who was married at 16 to a politically powerful man in the village, took the view that she does not need to go out to work when she can live like a 'princess' in her home.

At the community level, affluent households are less likely to be vulnerable to climate impacts, due to relatively higher adaptive capacity (Batool and Saeed 2018). Women from wealthier households in both the districts are less likely to engage in climate-sensitive activities like farm labour or be involved in collecting water. For educated women from the economically better-off households, teaching is considered the most respectable occupation, if they work at all. Healthcare work is considered acceptable 
by women from middle-income backgrounds; however, for women from economically or politically powerful backgrounds in the village (such as the village chief or large landowners), healthcare work involving door-todoor services is not socially acceptable. Men and women from households across income and landholding categories in both areas preferred women to be involved in home-based occupations such as tailoring or embroidery, although this was often not possible for the poor.

\section{Inter-generational dynamics and decision making}

Interactions with women and men farmers in Dera Ghazi Khan and Faisalabad showed that generational differences also shape gendered climate vulnerability. About half of rural households in the study sites included large extended families, which confer varying roles, status and power on women according to their social and economic position. The intra-household dynamics in joint families are much more complex than in nuclear ones. The position of a woman in such a household is defined according to her relation to the head of the household as well as other women in the family. Household dynamics also determine women's role in decision making and access to resources, defining their level of vulnerability (Nizami and Ali 2017). The older women in the family usually have the highest decision-making powers and are often consulted by the men in major household matters, including household resource management and migration decisions. These trends were observed across the two districts, reflecting a broader social culture at play in the province.

For example, in response to the declining profitability of agriculture, Zahida (aged 37) recalls that her husband left MorJhangi (Dera Ghazi Khan district) and decided to seek work outside the village. Her mother-in-law was involved in the decision as to where her husband should move to, but being a new bride, she was not involved in the discussion. She mentioned that she used to face mobility restrictions imposed by her mother-in-law, who did not allow her to go out of the house alone, even to run errands, but as her children are grown up now, these restrictions have eased.

Men's migration may also shift the household dynamics regarding responsibilities and decision making. We thought that with men migrating, women might have greater economic and social status and decision-making authority. However, due to the wide prevalence of joint or extended family systems, especially in Dera Ghazi Khan, the migrant's brother often takes over as the head of the household. Sometimes, as in the case of Zahida, women's mobility is further restricted to avoid gossip about them while their husbands are away. However, these changes in decision-making authority also depend on the age and household status of women. Older women may enjoy more authority in household affairs, but younger women, especially newly married ones, may face further restrictions in their husband's absence.

While there are considerable differences between households, young girls from poorer families are more likely to be taken out of school if the 
household income falls due to a climate shock. Even for better-educated women, work opportunities in the village are scanty, thus their educational qualifications often do not match their livelihoods or earning potential. For example, Nasima, 57, belonging to a large landholder household in MorJhangi (district Dera Ghazi Khan), complained that while she had ensured that her daughter completed her bachelor's degree, the girl is now unemployed. There are no opportunities in the village and her father does not allow her to move to the city to work. Nasima feels that the investment in her daughter's education has been wasted.

Besides inter-generational dynamics, decision-making responsibilities within the household are often starkly gendered. While women are active in farming activities in both the study areas, their contribution to farm-related decision making, across socio-economic categories, is limited. As mentioned earlier, many women consider their roles as 'fixed' as opposed to socially constructed and do not think their contribution to agriculture and as the family caregiver is underrated. This further reinforces the exclusion of women from decision-making processes in agriculture and climaterelated matters at the household level and undermines their ability to deal with climate shocks. Most of the women farm-labour respondents in Dera Ghazi Khan reported that they were not consulted about any farm-related decisions after the mega-floods of 2010. Men, on the contrary, said that they took most of the decisions in consultation with women household members, especially the older ones. Despite these consultations, however, men usually have the final say in most matters. Shabbir, a 62-year-old small landowner in Basti Raman in Dera Ghazi Khan stated: "We discuss at home what we should grow on the farm between wheat and cotton. My wife wants to grow vegetables, but I also have to see what would be more profitable in the market."

Day-to-day farm-level decisions regarding crops, seeds, fertilizer and pesticide choices and the area under each crop are often taken independently by men. Men farmers in Dera Ghazi Khan and Faisalabad felt they should be the ones taking farm-level decisions as women lack technical education about crop management, including checking insect population levels, soil moisture and crop water requirements. Here, the difference in the level of education between men and women farmers plays a major role. Most male farmers interviewed had completed primary school while their wives were mostly uneducated or informally educated, leading men to assume that women have limited skills and information. This stereotype prevails in the local administration, evident from the fact that agricultural training and information about new technologies are directed towards men. Shabana, a 57-year old widow in Faisalabad, manages her own small market garden. She receives money from her son working in Karachi, but she complains that she could make money by selling her produce if she had training on how to increase production. She informed us that she sometimes has to rely on her brother-in-law for agricultural advice. 
The exclusion of women from agricultural extension training also results in information closure, with women's access to critical information limited by system design. In line with this, men reported a higher degree of awareness about climate change and its impacts on agricultural productivity than women. The majority of the women respondents in both areas were unaware of any current or potential impacts of changes in weather patterns on the crop. In the villages in both Dera Ghazi Khan and Faisalabad, the major factor limiting women's access to information was the absence of any rural women's organization to facilitate information dissemination and ensure women's participation in agricultural decision making. While some non-governmental organizations are working in rural Dera Ghazi Khan to empower women by enhancing their skills, they largely provide training in tailoring and embroidery. Men, on the other hand, are represented by a number of formal and informal small-farmers' organizations which are also a major source of climate risk information at community level. Discussions with women in Dera Ghazi Khan revealed that women did not feel the need for women farmers' organizations. This perhaps reflects the deep-rooted patriarchal structures that limit women's capacity to think of themselves as involved in farm-level decision making.

Similarly, a dichotomy exists between men and women about perceived needs related to adaptation. Most men in both the study regions felt that women have no role in adaptation decision making as they are not fully aware of climate impacts and lack technical knowledge about farm management. Women are excluded from day-to-day farm-related decisions; thus, they too feel that they cannot contribute effectively to farm management decisions before and after climate disasters. Hence, social and cultural factors play a major role in compounding the adverse impacts of climate extremes for women in rural Pakistan.

It is worth noting here that while adaptation strategies related to productive processes (e.g., earning an income, maintaining agricultural activity) are more male-centric, women play an important role in private adaptation in response to shocks and stresses (Angula and Menjono 2014). Evidence from the field surveys in Dera Ghazi Khan and Faisalabad shows that in response to food insecurity due to climate shocks, men largely think in terms of modification of farm production, diversification of income activities, migration and relying on external help as effective coping strategies. This approach clearly reflects their control over assets and social mobility. Women, on the other hand, rely on short-term solutions like reducing food consumption, selling off household assets and reducing non-food expenditure to deal with food insecurity.

\section{Conclusion}

The accounts presented in this chapter reflect the fact that how women are affected by extreme climate events depends on the context and their involvement in agriculture and natural-resource management. Women in poorer 
socio-economic regions, such as Dera Ghazi Khan, tend to be more vulnerable to adverse climate situations than those in slightly better-off areas, such as Faisalabad. However, not all women in a specific region are affected uniformly. We have argued that within these regions, gender differentiation in experiences and responses to extreme climate events are not only classbased but also depend on women's intra-household position. Contextual factors such as the nature of men's and women's work, their control over productive resources, decision-making power and access to opportunities for learning, determine their experiences in relation to climate change. Our results reflect that normatively, while cultural norms in both the districts are largely similar, they are less rigid in Faisalabad, giving women greater mobility and the chance of engaging in non-climate-sensitive employment opportunities, making them less vulnerable than women in Dera Ghazi Khan.

However, such opportunities are often limited for the majority of women from poorer socio-economic backgrounds, who labour in the fields of the big landowners. Women from slightly higher socio-economic classes prefer home-based work, like making handicraft items, over agricultural labour, despite the extremely low returns, as it allows them to earn staying at home. Women from more educated and better-off backgrounds prefer to be employed in the healthcare or teaching sectors. A higher socio-economic position and lesser involvement in climate-sensitive activities decreases their vulnerability.

Our study shows that while older women have higher involvement in household decision making, men still dominate crucial adaptation decisions, especially those related to agriculture. This is not only the result of a patriarchal culture of control over assets and resources, but of patriarchal government policies that target only men for agricultural training and extension programmes. Although the National Climate Change Policy (2012) and the Framework for Implementation of National Climate Change Policy (2014) recognize the need for mainstreaming gender concerns in adaptation measures, all the action points are expressed in gender-neutral language and do not specifically recognize the need to enhance the adaptive capacity of rural women. While the socially constructed gender roles do put women at risk of higher vulnerability to climate change, recognizing women and men's "differentiated but complementary" roles (Rao et al. 2017) within the household and society may allow policy makers to better address the needs of the rural population, and poor women in particular. In that sense, building climate resilience for both women and men cannot just be driven by mainstreaming gender in climate policy: it also requires women's needs to be integrated into all other national and local policies and actions that shape and construct discriminatory gender roles in society and within households. This approach, in fact, shows that vulnerability is not an inherent characteristic of women; rather it is generated by the existing discrimination that women experience (Morchain et al. 2015). Understanding the contextual factors is important for determining women's level of vulnerability to climate change, in order to devise mechanisms to improve their resilience. 


\section{Notes}

1 Pathways to Resilience in Semi-arid Economies (PRISE) is a five-year, multicountry research programme that aims to create new knowledge about climateresilient and equitable economic development in semi-arid regions of Asia and Africa.

2 For more information, please refer to Salik et al. (2017) and Qaisrani et al. (2018).

3 For more information, please refer to Batool and Saeed (2017) and Batool and Saeed (2018).

4 Districts are the second-order administrative units of Pakistan, after provinces.

\section{References}

Akhtar, Saira, Ramzan, Shazia, Ahmad, Shabbir, Huifang, Wu, Imran, Shakeel and Yousaf, Haroon. 2018. 'Women in Agriculture - Lack of Access to Resources (An Analytical Study of District Faisalabad, Punjab, Pakistan)', SSRG International Journal of Economics Management Studies, 5(10): 16-24.

Angula, Margaret and Menjono, Ewaldine. 2014. 'Gender, Culture and Climate Change in Rural Namibia', Journal for Studies in Humanities and Social Sciences, 3(1\&2): 225-238.

Asian Development Bank (ADB). 2017. Climate Change Profile of Pakistan. Asian Development Bank (ADB): Manila, Philippines.

Babugura, Agnes. 2010. Gender and Climate Change: South Africa Case Study. Cape Town: Heinrich Böll Stiftung-Southern Africa.

Bates, Bryson, Kundzewicz, Zbigniew, Wu, Shaohong and Palutikof, Jean. (eds). 2008. Climate change and water. Technical Paper of the Intergovernmental Panel on Climate Change, IPCC Secretariat, Geneva.

Batool, Samavia and Saeed, Fahad. 2017. Mapping the Cotton Value Chain in Pakistan: A Preliminary Assessment for Identification of Climate Vulnerabilities and Pathways to Adaptation. Islamabad: Pathways to Resilience in Semi-arid Economies (PRISE). https://prise.odi.org/research/mapping-the-cotton-valuechain-in-pakistan-a-preliminary-assessment-for-climate-vulnerabilities-andpathways-to-adaptation/. Accessed on 15 October 2017.

Batool, Samavia and Saeed, Fahad. 2018. Towards a Climate Resilient Cotton Value Chain in Pakistan: Understanding Key Risks, Vulnerabilities and Adaptive Capacities. Islamabad: Pathways to Resilience in Semi-arid Economies (PRISE). https://prise.odi.org/research/towards-a-climate-resilient-cotton-valuechain-in-pakistan-understanding-key-risks-vulnerabilities-and-adaptivecapacities/. Accessed on 14 October 2017.

Cheema, Muhammad Asghar, Farooq, Muhammad, Ahmad, Rashid, and Munir, Hassan. 2006. 'Climatic trends in Faisalabab (Pakistan) over the last 60 years (1945-2004)', Journal of Agriculture \& Social Sciences, 2(1): 42-45.

Climate and Development Knowledge Network (CDKN). 2014. The IPCC's Fifth Assessment Report: What's in it for South Asia? https://cdkn.org/wp-content/ uploads/2014/04/CDKN-IPCC-Whats-in-it-for-South-Asia.pdf. Accessed on 17 August 2018.

D’Souza, Rohan. 2006. 'Water in British India: The Making of a Colonial Hydrology', History Compass, 4(4): 621-628.

Farooq, Umar, Ahmad, Munir and Saeed, Ikram. 2009. 'Enhancing Livestock Productivity in the Desert Ecologies of Pakistan: Setting the Development Priorities', The Pakistan Development Review, 48(4): 795-820. 
Fischer, Gunther, Shah, Mahendra and van Velthuizen, Harrij. 2002. Climate Change and Agricultural Vulnerability. Laxenburg: International Institute for Applied Systems Analysis.

Government of Pakistan. 2010. Agricultural Census: Punjab Province Tabulation. Islamabad: Government of Pakistan, Statistics Division.

Government of Pakistan. 2012. National Climate Change Policy. Islamabad: Ministry of Climate Change.

Government of Pakistan. 2014. Framework for Implementation of National Climate Change Policy. Islamabad: Ministry of Climate Change.

Government of Pakistan. 2016. Pakistan Economic Survey 2015-16. Islamabad: Government of Pakistan.

Government of Pakistan. 2017. Population Census: Provisional Summary Results of 6 th Population and Housing Census. Islamabad: Pakistan Bureau of Statistics.

Government of Pakistan (GoP) and United Nations Development Programme (UNDP). 2016. Multidimensional Poverty in Pakistan. Islamabad: Government of Pakistan.

Hahn, Micah, Riederer, Anne and Foster, Stanley. 2009.'The Livelihood Vulnerability Index: A Pragmatic Approach to Assessing Risks from Climate Variability and Change-A Case Study in Mozambique', Global Environmental Change, 19(9): 74-88.

Hasson, Shabeh, Bohner, Jurgen and Lucarini, Valerie. 2017. 'Prevailing Climatic Trends and Runoff Responses from Hindukush-Karakoram-Himalaya, Upper Indus Basin', Earth System Dynamics, 8: 337-355

Hussain, Syed Sajidin. 2010. Food Security and Climate Change Assessment in Pakistan. Oxfam Novib: Special Program on Food Security and Climate Change.

IPCC. 2013. 'Climate Change 2013: The Physical Science Basis.' Contribution of Working Group I to Stocker, T. F., D. Qin, G.-K. Plattner, M. Tignor, S. K. Allen, J. Boschung, A. Nauels, Y. Xia, V. Bex and P. M. Midgley (eds) Fifth Assessment Report of the Intergovernmental Panel on Climate Change. Cambridge, United Kingdom and New York, NY, USA: Cambridge University Press, p. 1535.

Ishaq, Wajiha and Memon, Shafique Qadir. 2016. 'Roles of Women in Agriculture: A Case Study of Rural Lahore, Pakistan', Journal of Rural Development and Agriculture, 1(1): 1-11.

Khan, Muhammad, Akhtar, Saima, Mahmood, Hafiz Zahid and Mahmood, Kashif. 2013. 'Analysing Skills, Education and Wages inFaisalabad: Implications for Labour Market', Procedia Economics and Finance, 5: 423-432.

Khan, Muhammad, Mahmood, Hafiz Zahid, Akhtar, Saima and Mahmood, Kashif. 2014. 'Understanding Employment Situation of Women: A District Level Analysis', International Journal of Gender and Women's Studies, 2(2):167-175.

KNMI (Koninklijk Nederlands Meteorologisch Instituut) (Royal Netherlands Meteorological Institute). 2017. Climate Explorer: Annual Temperature Data. https://climexp.knmi.nl/selectstation.cgi. Accessed on 14 May 2017.

LEAD Pakistan. 2015. LEAD Update: Local Adaptation Plan of Action for Dera Ghazi Khan. Islamabad: LEAD Pakistan. http://www.lead.org.pk/lead/ Publications/394-LAPA-\%20Community-based \%20Initiative\%20to \% 20 Reduce \%20the \%20Effects\%20of\%20Waterlogging\%20\&\%20Salinity.pdf. Accessed on 25 July 2019.

Liu, Chunzhen. 2002. 'Suggestion on Water Resources in China Corresponding with Global Climate Change', China Water Resources, 2: 36-37. 
MacGregor, Sherilyn. 2010. 'Gender and Climate Change: From Impacts to Discourses', Journal of the Indian Ocean Region, 6(2): 223-238.

Malana, Muhammad Aaslam and Khosa, Muhammad Arshad. 2011. 'Groundwater Pollution with Special Focus on Arsenic, Dera Ghazi Khan, Pakistan', Journal of Saudi Chemical Society, 15(1): 39-47.

Memon, Naseer. 2011. Climate Change and Natural Disasters in Pakistan. Karachi: Strengthening Participatory Organization (SPO). http://pnc.iucnp.org/wp/ wp-content/uploads/2011/10/ClimateChange_nmemon.pdf. Accessed on 16 August 2018.

MICS (Multiple Indicator Cluster Survey). 2018. Punjab: Survey Findings Report. Lahore: Bureau of Statistics, Planning and Development Board, Government of Punjab.

Mies, Maria. 1982. Lace makers of Narsapur: Indian Housewives Produce for the World Market. London: Zed Books.

Morchain, Daniel, Prati, Giorgia, Kelsey, Frances and Ravon, Lauren. 2015. 'What if Gender Became an Essential Standard Element of Vulnerability Assessments?', Gender and Development, 23(3): 481-496.

Mueller, Valerie, Gray, Clark and Kosec, Katrina. 2014. 'Heat Stress Increases Longterm Human Migration in Rural Pakistan', Nature Climate Change, 4: 182-185.

Nizami, Arjumand and Ali, Jawad. 2017. 'Climate Change and Women's PlaceBased Vulnerabilities - A Case Study from Pakistani Highlands', Climate and Development, 9(7): 662-670.

Pakistan Bureau of Statistics (PBS). 2015a. Labour Force Survey 2014-15. Islamabad: Government of Pakistan.

Pakistan Bureau of Statistics (PBS). 2015b. Pakistan Social and Living Standard Measurement 2014-15. Islamabad: Government of Pakistan.

Pakistan Meteorological Department (PMD). 2018. Dera Ghazi Khan: Cities Weekly Weather Outlook. Islamabad: PMD. http://www.pmd.gov.pk/meteorogram/ punjab.php? district=Dera+Ghazi+khan\&division=Dera \%20Ghazi\%20Khan. Accessed on 17 May 2017.

Panthi, Jeeban, Aryal, Suman, Dahal, Pyush, Bhandari, Parashuram, Krakauer, Nir, Pandey, Vishnu Prasad. 2016. 'Livelihood vulnerability approach to assessing climate change impacts on mixed agro-livestock smallholders around the Gandaki River Basin in Nepal', Regional Environmental Change, 16(4): 1121-1132.

PCSW (Punjab Commission on Status of Women). 2018. Women's Economic and Social Wellbeing Survey in Punjab 2017-18. Lahore: Government of Punjab.

Petesch, Patti, Bullock, Renee, Feldman, Shelley, Badstue, Lone, Rietveld, Annie, Bauchspies, Wenda, Kamazni, Adelbertus, Tegbaru, Amare and Yila, Jummai. 2018. 'Local Normative Climate Shaping Agency and Agricultural Livelihoods in SubSaharan Africa', Journal of Gender, Agriculture and Food Security, 3(1): 108-130.

Qaisrani, Ayesha, Umar, Muhammad Awais, Siyal, Ghamze Ali and Salik, Kashif Majeed. 2018. Rural Livelihood Vulnerability in Semi-Arid Pakistan: Scope of Migration as an Adaptation Strategy. Islamabad: Pathways to Resilience in Semiarid Economies (PRISE).

Rao, Nitya, Lawson, Elaine, Raditloaneng, Wapula, Solomon, Divya and Angula, Margaret. 2017. 'Gendered Vulnerabilities to Climate Change: Insights from the Semi-Arid Regions of Africa And Asia', Climate and Development, 11(1): 14-26.

Rao, Nitya, Gazdar, Haris, Chanchani, Devanshi and Marium Ibrahim. 2019. 'Women's Agricultural Work and Nutrition in South Asia: From Pathways to a Cross-disciplinary, Grounded Analytical Framework', Food Policy, 82: 50-62. 
Rasul, Ghulam, Zahid, Maida and Bukhari, Syed Ahsan Ali. 2012. Climate Change in Pakistan: Focused on Sindh Province. Islamabad: Pakistan Meteorological Department.

Saeed, Fahad, Suleri, Abid Qaiyum and Salik, Kashif Majeed. 2014. Planning for Floods: Now or Never. Policy Brief No. 44. Islamabad: Sustainable Development Policy Institute (SDPI).

Saeed, Fahad, Salik, Kashif Majeed and Ishfaq, Sadia. 2016. Climate Change and Heat Waves: Rural to Urban Migration in Pakistan. A Silent Looming Crisis. Islamabad: Sustainable Development Policy Institute (SDPI).

Salik, Kashif Majeed, Qaisrani, Ayesha, Umar, Muhammad Awais and Siyal, Ghamze Ali. 2017. Migration Futures in Asia and Africa: Economic Opportunities and Distributional Effects - The Case of Pakistan. Islamabad: Pathways to Resilience in Semi-arid Economies (PRISE).

Samee, Durre, Nosheen, Farhana, Khan, Haq Nawaz, Khowaja, Imdad Ali, Jamali, Khalida, Paracha, Pervex Iqbal, Akhtar, Shahnaz, Batool, Zahira and Khanum, Zohra. 2015. Women in Agriculture in Pakistan. Islamabad: Food and Agriculture Organisation of the United Nations.

Tiani, Anne Marie, Bele, Mekou Youssoufa, Kankeu, Richard Soufo, Chia, Eugene Loh and Teran, Alba Saray Perez. 2016. 'Gender and Forest Decentralisation in Cameroon: What Challenges for Adaptive Capacity to Climate Change?' In Colfer, Carol J. Pierce, Basnett, Bimbika Sijapati and Elias, Marlene (eds). Gender and Forests: Climate Change, Tenure, Value Chains and Emerging Issues. The Earthscan Forest Library. New York: Routledge, pp. 107-125.

UN Women. 2018. Rural Women in Pakistan: Status Report 2018. Islamabad: UN Women.

United Nations Development Programme (UNDP). 2013. Overview of Linkages between Gender and Climate Change. New York: UNDP.

World Bank. 2018. Labour Force Participation Rate for Women. World Development Indicators. The World Bank Group. https://data.worldbank.org/indicator/SL.TLF. CACT.FE.ZS. Accessed on 25 July 2019.

World Food Programme (WFP). 2018. Climate Risks and Food Security Analysis: A Special Report for Pakistan. Islamabad: World Food Programme.

Zaman, Qamar, Mahmood, Arif, Rasul, Ghulam and Afzaal, Muhammad. 2009. Climate Change Indicators of Pakistan. Islamabad: Pakistan Meteorological Department. 